\title{
UM INIMIGO NATURAL DOS CARAMUJOS DO GENERO BIOMPHALARIA
}

\author{
Alu ízio Bezerra Coutinho
}

\begin{abstract}
A formiga carnivora Paratrechina longicornis exerce predação ativa sobre os caramujos do gênero Biomphalaria. Assim que os caramujos são deixados no seco pela retirada ou dessecamento das águas na estação seca, são atacados e rapidamente devorados pelas formigas. Somente os caramujos enterrados na lama argilosa ou aqueles que tiverem a abertura das conchas obturadas por tampões de argila endurecida pela secura conseguem escapar à predação e retornarem à atividade quando a volta da estação chuvosa traz água para os vivedouros dessecados. Obviamente outras espécies de formigas carnivoras podem assumir idêntica função ecológica.
\end{abstract}

\section{INTRODUÇÃO}

Os caramujos do gênero Biomphalaria, cuja importância para o homem advém de serem eles os hospedeiros intermediários do trematódio Schistosoma mansoni, têm como habitáculo águas doces paradas e lugares remansosos nos rios e ribeiras de fluxo lento. Destes tipos de águas os mais importantes, onde pululam meIhor, são os charcos, tanto os permanentes, como os de carater temporário, isto é, coleções d'água astáticas que, na maioria dos casos, não merecem outra designação que a de poças transitórias. Em trabalhos anteriores, em $1940 \mathrm{e}$ $1945 \mathrm{com}$ vários colaboradores ${ }^{2},{ }^{3}$ tive ocasião de chamar a atenção para a importância do fenômeno descrito por Barlow ${ }^{1}$ no Egito e que consiste na sobrevivência dos caramujos des. secados e envolvidos na lama seca dos canais de irrigação, durante o estio, até que a chegada das águas com as inundações punha termo à estivação, reiniciando-se novo ciclo de atividade reprodutiva. Nestes trabalhos anteriores ficou salientada a importância epidemiológica desse fato, a ocorrência, nas conchas de caramujos de maior tamanho, dos sinais marcadores (estrias estivais) de cada período de estivação e também a possibilidade de os caramujos estivantes serem vítimas de agressão por parte de predadores, entre os quais logo me ocorreu a possível ação de formigas. Nas campanhas de que resultaram os trabalhos mencionados não foi possível a comprovação desta suspeita, embora tivesse sido assinalado que a repopulação dos charcos após a secura estival se fizesse a partir de um número muito pequeno de sobreviventes ${ }^{3}$. A interpretação adequada destes fatos requer admitir-se uma mortalidade maior dos caramujos estivantes no campo, de que nos conservados em laboratório, fato já suspeitado por ocasião do trabalho de $1940^{2}$. Foi isto que levou à sugestão de uma possível interação de predadores, capazes de liquidar com os caramujos imobiliados pela estivação.

A caracterização da responsabilidade de tais efeitos predatórios não foi conseguida durante as campanhas aludidas, mas veio finalmente a ser feita por ocasião dos trabalhos de campo patrocinados pelo CONDEPE durante as colheitas de material feitas na Lagoa de Arroz, municipio de Olinda no dia 06 de setembro de 1971.

A lagoa do Arroz é uma depressão situada na várzea do Rio Doce na altura do cotovelo

Departamento de Biologia geral, Centro de Ciências Biológicas, Universidade Federal de Pernambuco.

Recebido para publicação em 11.6.1976 
onde, ao se infletir, este rio torna-se paralelo à praia de Casa Caida, passando a correr por trás de um sistema de dunas arenosas baixas em direção ao norte, até desaguar no Oceano. Durante a época das chuvas essa área deprimida enche-se de águas tanto provenientes das precipitacões nela e nos terrenos adjacentes, como da própria inundação pelas águas crescidas do rio Doce. Cessadas as chuvas logo a drenagem natural pelo rio faz baixar as águas, vindo a lagoa a secar completamente ao terminar o estio. Nessa lagoa quando cheia, as condições são muito propícias para o desenvolvimento dos caramujos encontrando-se abundantemente formas grandes da Biomphalaria glabrata. A medida que o estio progride os caramujos vão ficando na terra seca onde passam a estivar retraindo-se as lesmas para as espiras centrais. Foi em uma ocasião mencionada que apanhei um caramujo que estava cheio de pequenas formigas negras, que devoravam a lesma ainda sangrenta. Este caramujo foi guardado separado dos demais, e as formigas trazidas junto com ele conservadas em álcool para identificação posterior.

A fim de identificar esta formiga, solicitei a ajuda do Professor Mário Bezerra Carvalho da Universidade Federal Rural de Pernambuco. Passado algum tempo o Prof. Mário Bezerra Carvalho comunicou-me haver enviado o material ao Prof. Lauro Travassos Filho do Instituto Butantã que em carta pessoal ao referido Professor informou:

“. . a aqui segue o nome da formiga, identificada pelo maior conhecedor do assunto Frei Walter Kempf, que acaba de publicar um catálogo completo de formigas Neotropicais, ocupando quase todo o volume XV da Studia Entomológica:

Paratrechina longicornis (Latreille, 1902) formiga cosmopolita carnivora, comum na ala litoranea do Brasil. Não só caça ativamente presas vivas, como desmontam rapidamente insetos e outros bichos que encontram".

Como se vê pela preciosa informação de Frei Walter Kempf, a Paratrechina longicornis aten- de todos os requisitos para a rápida destruição dos exemplares de Biomphalaria que estejam ao seu alcance. Para tanto basta que os caramujos venham a ficar em seco para que sejam localizados pelas infatigáveis patrulhas das formigas. A rapidez com que atuam limpando as conchas e abandonando-as, uma vez vazias, torna difícil surpreendê-las no ato da predação, e por isso somente uma vez foi-me possível fazê-lo. Dessa forma é possível darmo-nos conta da abundância de conchas vazias em torno dos habitáculos aquáticos de Biomphalaria sujeitos a oscilação de nível a mercê das variações das chuvas e inundações. Nada impede que outras espécies de formigas predadoras e carnívoras possam competir com a Paratrechina nesta função ecológica, cujo papel na eliminação dos estivantes a que tenham acesso é óbvio.

O fenômeno da agressão pode ser reproduzido facilmente. Caramujos de $15 \mathrm{~mm}$ de diâ. metro, em estivação, colocados junto aos formigueiros, são, uma vez localizados pelas formigas, reduzidas a conchas limpas no espaço de duas horas. Por outro lado caramijos cuja abertura tinha sido obturada com terra argilosa e postos a secar até o endurecimento do tampão argiloso, foram respeitados. Por isso penso que os caramujos que tenham ficado soterrados no lodo argiloso que depois foi endurecido pelo ressecamento, são aqueles que tem probabilidade de revivescer, quando forem libertos do aprisionamento pelas águas novas que reenchem os charcos. Não obstante sua voracidade, pelos menos as formigas da espécie Paratrechina longicornis não são suficientemente fortes ou armadas para vencer o obstáculo de uma camada de argila seca, dura, envolvendo um caramujo e obturando a abertura de sua concha.

\section{AGRADECIMENTOS}

Ao terminar esta nota quero reafirmar minha gratidão aos Professores Mário Bezerra Carvalho, Lauro Travassos Filho e Frei Walter Kempf, pela identificação da formiga e preciosas informações esclar ecedoras de seus hábitos.

\section{SUMMARY}

The carnivorous ant Paratrechina longicornis was found to be an active predator against estivating snails of the genus Biomphalaria. As soon as the snails are left in the dry land by the receding waters during the dry season, they are attacked and quickly eaten by the ants. Only the snails buried in the claysh mud or those which have their shell openings obturated by lumps of hardened clay are apt to escape predation and return to activity when the forthcoming wet season brings water to the dryed-up breeding sites. Obviously other species of carnivourous ants may play the same ecological role. 


\section{REFERÊNCIAS BILBIOGRÃFICAS}

1. BARLOW, C.H. - The effect of the winter rotation upon snails, involved in the spread of schistosomiasis in Egypt, - 1930 1931, Amer. Journ. of Hyg. 17: 724-742, 1933.

2. BEZERRA COUTINHO, A. \& LUCENA, D. - Investigações em torno de epidemiologia da esquistossomose mansônica em Pon- tezinha e Vitória. Pernambuco - Brasil. Mem. Inst. Oswaldo Cruz 35: 207-230, 1940

3. BEZERRA COUTINHO, A., \& A.L. Investigações sobre a ecologia do Australorbis glabratus, An. Fac. Med. Recife 17: 35, 1957. 